\title{
Quiz Case: A 19-Year-Old Woman with Hypercalcemia and Abdominal Pain
}

\author{
Flora Zagouri $^{\mathrm{a}}$ Nikolaos Thomakos ${ }^{\mathrm{b}} \quad$ Alexandros Rodolakis $^{\mathrm{b}}$ Aristotle Bamias $^{\mathrm{a}}$ \\ Athanassios Chalazonitis $^{c}$ Maria Sotiropoulou $^{d}$ Aris Antsaklis $^{a}$ \\ Meletios-Athanassios Dimopoulos $^{a}$ Christos A. Papadimitriou ${ }^{a}$ \\ ${ }^{a}$ Department of Clinical and Therapeutics, \\ bepartment of Obstetrics and Gynecology, Alexandra Hospital, School of Medicine, University of Athens, \\ 'Department of Radiology, 'Department of Pathology, Alexandra Hospital, Athens, Greece
}

\section{Keywords}

Hypercalcemia - Small ovarian cancer .

Hypercalcemic type of ovarian cancer

A 19-year-old Caucasian student presented at our hospital complaining of slight abdominal discomfort and flatulence that had persisted for 1 month. She reported no significant past or family history. Physical examination identified a massive, palpable mass in the lower and upper abdomen with no signs of induration or invasion of the parametrial and rectovaginal areas. There was no evidence of ascites.

Laboratory findings revealed remarkably elevated serum calcium (Ca: $17.3 \mathrm{mg} \%$ ) and serum phosphorus (P: $2.4 \mathrm{mg} \%$ ) and slightly elevated carcinoembryonic antigen (CEA) and cancer antigen 125 (CA125) (CEA: $0.2 \mathrm{ng} / \mathrm{ml}$ (normal range $<4.7 \mathrm{ng} / \mathrm{ml}$ ), CA125: $92 \mathrm{U} / \mathrm{ml}$ (normal range $<35 \mathrm{U} / \mathrm{ml}$ )). It is interesting that the young woman displayed no signs or symptoms of hypercalcemia.

Magentic resonance imaging (MRI) of the abdomen revealed a large lobulated lesion compressing the bicornuate uterus and the urinary bladder; it occupied the pelvic cavity and extended to the upper abdomen. During the days after administration of normal saline containing potassium chloride $(\mathrm{KCl} ; 10 \mathrm{mEq} / \mathrm{l})$ and zoledronate, the serum calcium dropped to normal levels. An exploratory laparotomy was performed. The gynecologist decided to adopt a conservative approach and performed a left salpingoophorectomy (the frozen section was positive for malignancy), infracolic omentectomy, systematic pelvic and para-aortic lymphadenectomy and appendicectomy.

Gross examination revealed an encapsulated ovarian tumor of $25 \mathrm{~cm}$ in its greatest diameter, as well as peritoneal implants exceeding $2 \mathrm{~cm}$. The cut surface of the tumor was solid, soft and white to tan in color with hemorrhages and necroses. Microscopic examination disclosed 2 patterns, the one with diffuse arrangement of small cells with scanty cytoplasm and the other with follicles varying from small to large with eosinophilic fluid in the lumen. In the 2nd pattern, the tumor cells had abundant eosinophilic cytoplasm. Mitotic figures were numerous ( $>30$ mitoses/high power field (HPF)). Immunohistochemically, the tumor's profile was as follows: positive for $\mathrm{p} 53$, vimentine, Wilms' tumor protein 1 (WT-1), CD99, and negative for thyroid transcription factor 1 (TTF1), calretinin, $\alpha$-inhibin, epithelial membrane antigen (EMA), placental alkaline phosphatase (PLAP) and CD10. Morphology and immunohistochemistry differentiated the tumor from juvenile granulosa cell tumor, dysgerminoma and small-cell carcinoma pulmonary type (fig. 1).

\section{What is Your Diagnosis?}

\section{Pathologic Diagnosis: Hypercalcemic Small Ovarian}

Carcinoma, Stage IIIC

Ovarian small-cell cancer of the hypercalcemic type (OSCCHT) is a rare and fatal neoplasm with rapid progression [1]. With just 70 cases reported in the literature, this neoplasm was first described by Dickersin and Scully in the 1980s [2]. Para-endocrine hypercalcemia is displayed in about $60 \%$ of the cases. The predominantly unilateral tumor most commonly affects young women in the 2nd and 3rd decade of their lives [3]. Pathologically, OSCCHT is characterized by sheets of closely packed, small cells with scanty cytoplasm forming scattered, follicle-like structures; the morphologic similarity to sex cord stromal tumors and germ cell tumors may pose significant problems for a correct diagnosis [2, 3].

The prognosis is generally very poor; 1-year survival reaches just $50 \%$, while the overall 5 -year survival rate is

\section{KARGER}

Fax +497614520714

Information@Karger.de

www.karger.com (c) 2012 S. Karger GmbH, Freiburg

0378-584X/12/0353-0126\$38.00/0

Accessible online at:

www.karger.com/onk
Flora Zagouri, $\mathrm{MD}, \mathrm{PhD}$

Department of Clinical and Therapeutics, Alexandra Hospital

School of Medicine, University of Athens

Vas. Sofias Ave and Lourou str, Ampelokipi, Athens 11528, Greece

Tel. +30 21 03381-545, Fax -511

florazagouri@yahoo.co.uk 


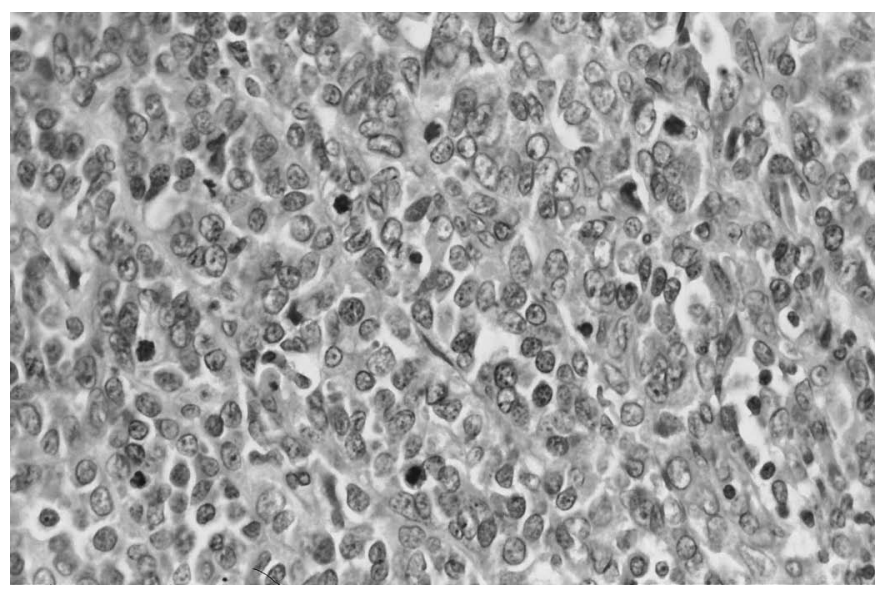

Fig. 1. Diffuse arrangement of small, closely packed cells with scanty cytoplasm and high mitotic rate $(\times 400)$.

approximately $10 \%$ [3]. It is worth mentioning that our patient died 8 months after the initial diagnosis from ileus, owing to disease progression. The patient had received, as 1st-line treatment, 3 cycles of etoposide $80 \mathrm{mg} / \mathrm{m}^{2}$ (days 1-3) combined with cisplatin $80 \mathrm{mg} / \mathrm{m}^{2}$. Due to progression of the disease, she was later given 2 cycles of capecitabine $1,000 \mathrm{mg} /$ $\mathrm{m}^{2}$ (days 1-14) combined with cisplatin $80 \mathrm{mg} / \mathrm{m}^{2}$ on day 1 (at every 21-day cycle), whilst 2 cycles of paclitaxel $\left(90 \mathrm{mg} / \mathrm{m}^{2}\right.$ on days $1,8,15)$ combined with bevacizumab $\left(10 \mathrm{mg} / \mathrm{m}^{2}\right.$ on days $1,15)$ were administered as third-line treatment. The disease continued to progress and the patient died approximately 1 month later.

The optimal management of OSCCHT remains unknown; unfortunately, clinical trial reports are lacking and conclusions have been drawn from observations either of case reports or retrospective analyses, which restricts the interpretation and application of the results. Nevertheless, accumulating data suggest that a combination of radical surgery, radiotherapy, adjuvant multiagent chemotherapy and consolidation high-dose chemotherapy has the most favorable outcome in terms of survival $[1,2,4,5]$.

\section{Disclosure Statement}

There is no financial support or relationship that may pose any conflict of interest.

\section{References}

1 Distelmaier F, Calaminus G, Harms D, Sträter R, Kordes U, Fleischhack G, Göbel U, Schneider DT: Ovarian small cell carcinoma of the hypercalcemic type in children and adolescents: a prognostically unfavorable but curable disease. Cancer 2006; 107:2298-2306.

2 Pautier P, Ribrag V, Duvillard P, Rey A, Elghissassi I, Sillet-Bach I, Kerbrat P, Mayer F, Lesoin A, Brun B, Crouet H, Barats JC, Morice P, Lhommé $\mathrm{C}$ : Results of a prospective dose-intensive regimen in 27 patients with small cell carcinoma of the ovary of the hypercalcemic type. Ann Oncol 2007;18:1985-1989.

-3 Young RH, Oliva E, Scully RE: Small cell carcinoma of the ovary, hypercalcemic type. A clinicopathological analysis of 150 cases. Am J Surg Pathol 1994;18:1102-1116.

4 Dykgraaf RH, de Jong D, van Veen M, EwingGraham PC, Helmerhorst TJ, van der Burg ME: Clinical management of ovarian small-cell carci- noma of the hypercalcemic type: a proposal for conservative surgery in an advanced stage of disease. Int J Gynecol Cancer 2009;19:348-353.

5 Harrison ML, Hoskins P, du Bois A, Quinn M, Rustin GJ, Ledermann JA, Baron-Hay S, Friedlander ML: Small cell of the ovary, hypercalcemic type - analysis of combined experience and recommendation for management. A GCIG study. Gynecol Oncol 2006;100:233-238. 